\title{
49. 大動脈永久遮断要する術式における
}

\section{Stapler の応用と開発}

\section{小田桐重遠* 石 倉 義 弥* 吉 松 博* 杉浦仁臣*2 井上 遷*2}

\section{1.はじめに}

弓部〜下行大動脈瘤は, 近年その補助手段, 手術方法にさまざまの工夫が加えられ長足の進 歩をとげてきたが1)，その手術成績はいまだ満 足すべきものとはいえない．

われわれは本症において，左開胸が不利と考 えられる症例, poor risk の症例などに対する 1 つの方法として, 上行〜腹部大動脈間の永久 バイパス法と䪤空置法の併用により，比較的良 好な結果を得ている2)，われわれは本法の瀷空 置に際し，大動脈の永久遮断の目的で, 高砂医 科工業より金属縫合器を試作したのでその基礎 的検討と臨床応用について報告する。

\section{2. 基礎的検討}

プロトタイプの縫合器を用いた基礎的実験は すでに報告したが3)，そのうちの病理学的検索 として，肉眼的にみると多くの症例で大動脈内 膜面で内膜の断裂は認放ず, leakもほとんどな く smooth な遮断が得られたが，なかには内膜 の亀裂や中膜弾性線維に対する高度の圧迫所 見, 部分的な断裂などの所見も認めることもあ った（図 1, 図 2).

このために staplerをしめる時の力かげんが 大事となる。したがって一定の力でしめるには stapler のかみ合わせ部分をある一定の間隔に すればよいことになる。しかしあまり間隔をあ けすぎると staples がずれることがあるのでこ の点を検討した結果， staplerのかみ合わせ部 分を $3 \mathrm{~mm}$ までならば，ずれることがなくかみ 合わせ可能であることがわかった。

* 産業医科大学第 2 外科

*2 高砂医科工業(林

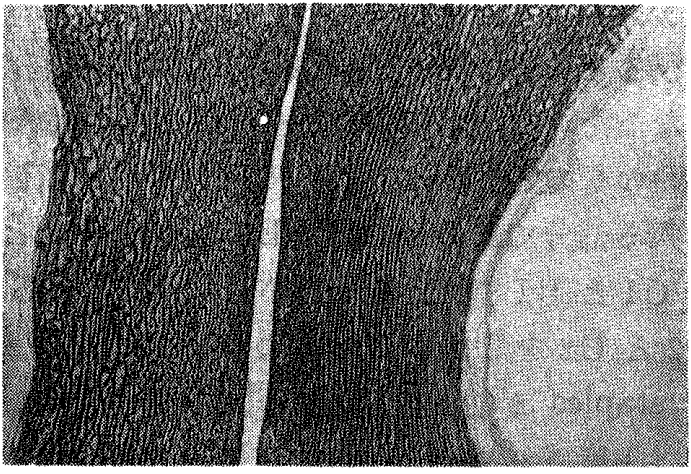

図 1 病理学的所見で内膜の龟裂や中膜弾 性線維の断裂は認めないものもある

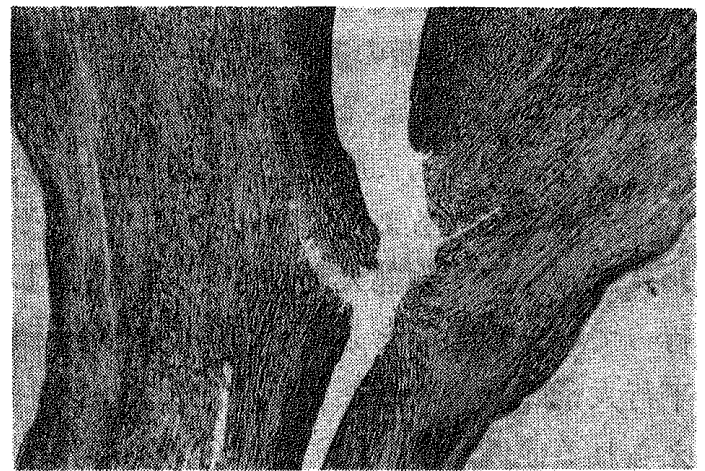

図 2 中膜の弾性線維の断裂之内膜の損倒 を認めるものもある

\section{3. 試作した金属繾合器（図 3)}

staples は幅 $8 \mathrm{~mm}$, 脚の長さ $7 \mathrm{~mm}$ とし, B shape にとじこまれた時の幅は $3 \mathrm{~mm}$ とな るようにした。したがって大動脈と stapler の 間には薄手のダクロンフェルトでないと縫合不 能である。なお材質はステンレススチールを用 いているが，将来はチタンなども応用する予定 である、stapler は図 3 に示すように，かみ合 わせ部分の長さは $7 \mathrm{~cm}$ とし, staples がたが いちがいになるよう 2 列とした。 大動脈後壁に 
医器学 Vol. 53, Suppl. (1983)

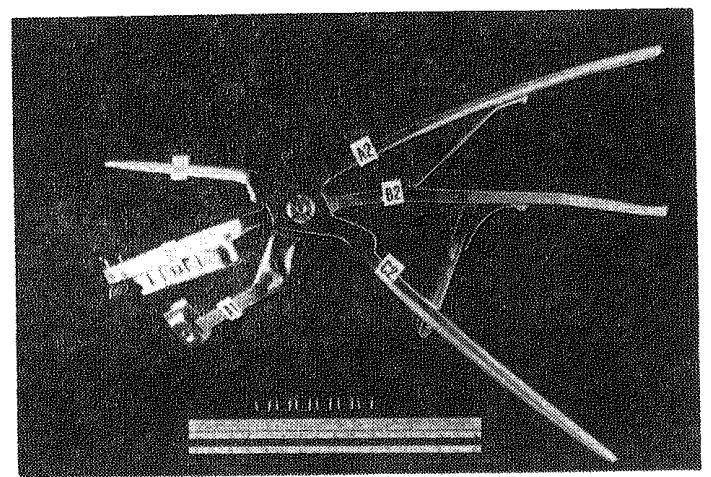

図 3 試作した金属梿合器（説明は本文中）

入る部分は細い方がよいわけであるが，細くし すぎると， staplesをしめる時の力がかからな くなるために通常の大動脈錩子などよりやや大 きめのものとなった．C1 の部分が大動脈後壁 に入る部分であるが $\mathrm{C} 2, \mathrm{~B} 2$ をつかむことよ り $\mathrm{C} 1$ と B1で大動脈をはさみこむ.さらに A2 とC2をしめることにより B1 亿内藏され た staples が屈曲し遮断が可能となる。この 際， 1 度にしめると stapler の先端と根部での 圧力が均等に配分されないおそれのあるため に，かみ合わせの B1 の部分を 3 分し， 3 段階 に圧迫するように工夫した。

\section{4. 大動脈永久遮断の適応}

Carpentier らによる Thrombo-exclusion 法が行われて以来"，解離性大動脈溜において はしばしば行われるようになってきたが，その 他われわれは真性胸部大動脈瘤の一部に対して も行っている. 適応としては, (1)右の低肺機能 や下行大動脈瘤の破裂などで, 左開胸が不利と 考えられる症例, (2)左胸腔全域にわたる巨大動 脈瘤, (3)下行大動脈の人工血管の感染例, (4) poor risk で人工心肺も左開胸もやりたくない ような症例などが考えられる。

またその利点としては, (a)ハパス作製に際 して大動脈の完全遮断の必要のないこと, (b中 枢側の吻合が容易なこと，〕全身一パリン化の 必要のないことなどがあげられる.

\section{5. 臨床応用}

51 歳男性の 解離性大動脈瘦 DeBakey III 型 に対し上行〜腹部大動脈間に人工血管による extra-anatomical-bypass 設け，さらに左頸 動脈と左鎖骨下動脈にも $\mathrm{Y}$ 型人工血管にてバイ パスし，われわれの開発した金属縫合器にて遮

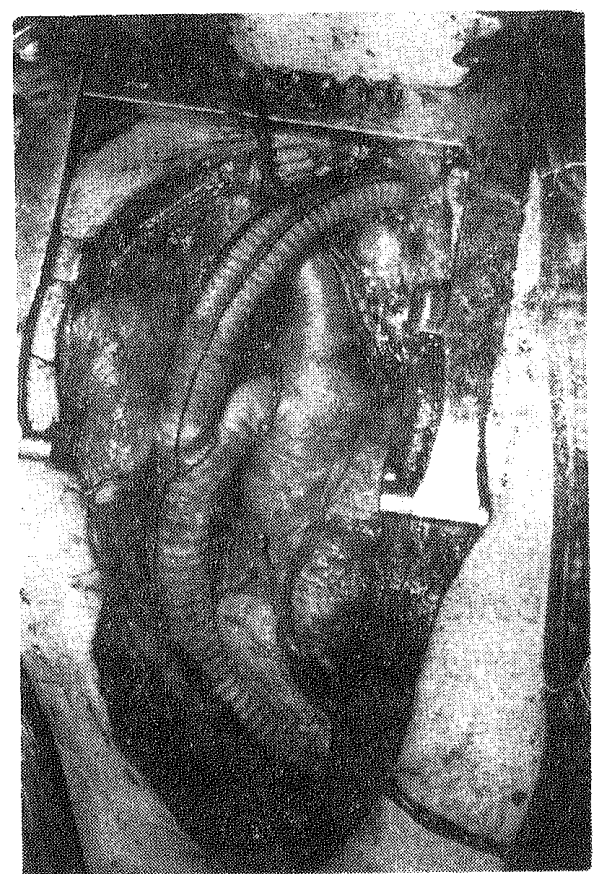

図 4 解離性大動脈瘦に対する臨床応用 (Stapler に加えさらに手䋖いでも補強 した)

断を行い，末梢側はTh 8 まで血栓性閉塞があ ったのでその位置にて切断を行った.

中枢側遮断には薄手のダクロンフェルトを大 動脈壁との間に挿入乙，同部位からの出血はほ とんどなかった（図4）。

\section{6. 考 案}

大動脈を永久遮断を行う場合, 多くの施設で は手縫いによる方法がとられているが，近年 Carpentier ら () による Thromboexclusion 法 が多く行われるようになってきたため，彼らの 大動脈クリップが多く用いられるようになって きた。安た本邦に㧍いても島津ら゙)により新し いクリップの開発も行われている.

この方法の利点は術式を単純化した点にある と考えられるが, 術野の後方での操作が難しい と思われる点, クランプの両端がややかさばる ことにより，肺動脈や気管支などを圧迫するの ではないか,クランプのしめぐあいをどうする かなどで問題点がある.

器械縫合器は一般消化器外科, 肺外科などで は諸種の型式が開発され, 多くの臨床応用が行 われ良好な成績が得られている。

われわれもプロトタイプとして慶大外科食道 グループにより開発された縫合器を用いて基礎 
実験を行い，今回の新しい縫合器を開発したわ けであるが，この方法ではクランプの久点であ るかさばることもなく, 大動脈後壁の操作は簡 単に行え，しかも瞬時に遮断が完了する利点が あると思われる。

臨床応用にても遮断部位からの出血もほとん ど認めず良好な結果が得られた。

\section{7. 結 論}

大動脈永久逘断の目的で新しい金属縫合器を 試作した。いまだ臨床応用は 1 例のみであるが 良好な結果が得られた，今後遠隔期においてい かなる変化があるかなど不明の点も多いので慎 重な follow up が必要であると考えている.

\section{文献}

1) Crawford S.E. and Saleh S.: Transverse Aortic Arch Aneurysm. Improved Results of Treatment Employing New Modification of Aortic Reconstraction and Hypothermic Circulatory Arrest. Ann. Surg. 194: 180, 1981

2) 小田桐重遠, 川田光三, 相馬康宏, 今村洋二, 井上正, 宮崎泰弘: 弓部 下行大動脈瘤に対す る上行〜腹部大動脈永久バイパス法の 4 例. 日 胸外会誌, $30: 437,1982$

3）小田桐重遠, 石倉義弥：上行大動脈～腹部大動 脈永久バイパス法における大動脈永久遮断に対 する縫合器の応用. 医器学, 52 : Suppl. 26, 1982

4) Carpentier A, Deloche A, Fabiani JN, Chauvaud S, Relland J, Nottin R, Vouhe P, Massoud $\mathrm{H}$ and Dubost $\mathrm{CH}$ : New surgical approach to aortic dissection: Flow reversal and thromboexclusion. J. Thorac. Cardiovasc. Surg. $81: 659,1981$

5）島津和彦, 橋本明政, 小柳仁：解離性大動脈溜 に対する Permanent Aortic Clamp を用いた 新しい術式の開発. 脈管学, $21: 574,1981$

50. 新しい骨縫合・固定法

横山正義* 和田 寿 郎* 長 柄英 男* 笠 置 康* 板岡俊成* 毛井俊 一 * 田村富士夫*2

\section{1. 目 的}

胸部外科手術では胸骨を縦切開したり，横切 開したりすることが多い：また鎖骨や肋骨を切 断することもある。目的とした臟器の外科的修 復後, これら胸骨や鎖骨・肋骨をステンレスワ イヤで縫合固定しなければならない。

胸骨にワイヤを通すため，太いワイヤつき角 針が使用されている．ステンレスワイヤの直径 が $0.8 \mathrm{~mm}$ でも，角針の長径は $1.6 \mathrm{~mm}$ であ る（図 1 ），術者の強力な力でこのワイヤつき 角針を胸骨に貫通させる，大人では胸骨が厚 く，固くなっており，なかなか角針が貫通しな い. 成人で胸骨の最む厚い部分は $2.5 \mathrm{~cm}$ の厚 さがある。この部に角針をさし込むことは困難

* 東京女子医科大学胸部外科

*2 第二精工舎㑣電子設計

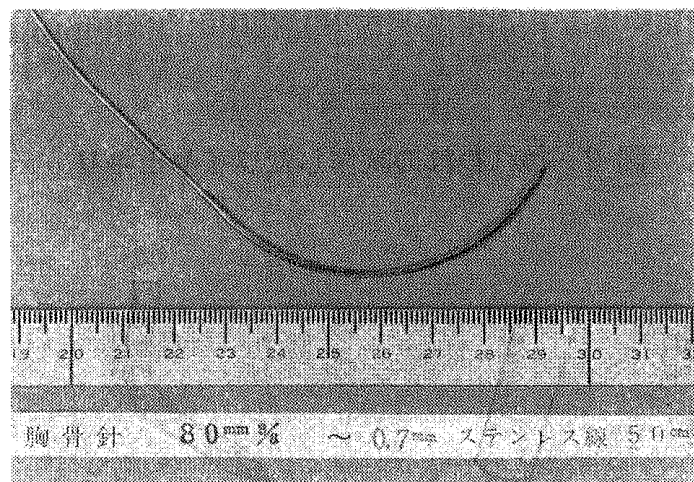

図 1 現在一般に使用されている胸骴針

である，力いっぱい角針を胸骨にさし込むと， その強力な力のために胸骨骨折なども生じる. 一方，角針の直径がステンレスワイヤ直径より 太いため角針が貫通した胸骨部から出血が生じ ることもある。

著者らは容易に胸骨にワイヤを通す方法を研 